Pacific Journal of Mathematics

CRITERIA FOR ZERO CAPACITY OF IDEAL BOUNDARY 


\title{
CRITERIA FOR ZERO CAPACITY OF IDEAL BOUNDARY COMPONENTS OF RIEMANNIAN SPACES
}

\author{
WELLiNGTON H. OW
}

\begin{abstract}
Capacities of ideal boundary components of Riemannian spaces are introduced to measure their magnitude with respect to harmonic functions on the spaces. The main purpose of this paper is to find zero capacity criteria.

The modular criterion, well-known for Riemann surfaces, i.e. for 2-dimensional Riemannian spaces, is shown to be valid for general Riemannian spaces. The so-called metric criterion, however, brings forth entirely new aspects for higher dimensions.
\end{abstract}

\section{CAPACITY of a SubBoundary}

1. Subboundaries. Throughout this paper we denote by $R$ a noncompact orientable connected $C^{\infty}$ Riemannian space. A relatively compact region whose relative boundary is smooth will be called a regular region. A sequence $\left\{R_{n}\right\}_{1}^{\infty}$ of regular regions $R_{n} \subset R$ such that $\bar{R}_{n} \subset R_{n+1}$ and $R=\bigcup_{1}^{\infty} R_{n}$ is called an exhaustion of $R$.

The ideal boundary component of Kerékjártó and Stoillow may be related to $\left\{R_{n}\right\}$; here $R-\bar{R}_{n}$ can be assumed to consist of a finite number of relatively noncompact regions $F_{n i}$ with corders $\beta_{n i}$. Choose a sequence $F_{1}=F_{1 i_{1}}, F_{2}=F_{2 i_{2}}, \cdots$ such that $\bar{F}_{n+1} \subset F_{n}$. Then $\left\{F_{n}\right\}_{1}^{\infty}$ defines a boundary component $\gamma$. We denote by $\gamma_{n}$ the relative boundary $\partial F_{n}$ of $F_{n}$.

A subboundary, also to be denoted by $\gamma$, is a union of boundary components.

2. Capacity function. Let $B$ be a parametric ball about $a \in R$ with compact $\bar{B}$. Suppose $\gamma$ is a subboundary of $R$, and $\gamma_{n}$ the union of all $\partial F_{n}$ such that $\left\{F_{n}\right\}_{1}^{\infty}$ defines a boundary component belonging to $\gamma$.

Consider the family $P=\{p\}$ of harmonic functions $p$ on $R-a$ such that (a) $p=-g_{a}+h$ in $B$ where $g_{a}$ is the Green's function of $B$ with pole at $a$, and $h$ a harmonic function on $B$ with $h(a)=0$, (b) $\int_{\gamma_{n}} * d p=1$ and $\int_{\beta_{n i} \notin \gamma_{n}} * d p=0$ for large $n$, where the $\beta_{n i}$ are components of $\partial R_{n}$.

We use the conventional notations

$$
\int_{r} * d p=\lim _{n \rightarrow \infty} \int_{\gamma_{n}} * d p .
$$




$$
\int_{\beta} p * d p=\lim _{n \rightarrow \infty} \int_{\beta_{n}} p * d p,
$$

$\beta$ being the entire boundary of $R$.

Amalgamating the method of Sario [1] with the existence theorem of principal functions in Sario-Schiffer-Glasner [2], we can easily see that $P$ is not empty and that there exists a function $p_{r} \in P$ such that

$$
k_{\gamma}=\min _{P} \int_{\beta} p * p d=\int_{\beta} p_{\gamma} * d p_{\gamma} .
$$

Here $-\infty<k_{\gamma} \leqq \infty$, and if $k_{\gamma}<\infty$, then $p_{\gamma}$ is unique. This follows from the identity

$$
\int_{\beta} p * d p=D\left(p-p_{\gamma}\right)+\int_{\beta} p_{\gamma} * d p_{r},
$$

where $D$ indicates the Dirichlet integral.

The function $p_{r}$ shall be referred to as a capacity function for $\gamma$. The quantity $c_{r}=e^{-k_{\lambda}}$ for $\operatorname{dim} R=2$, and $k_{r}^{-(m-2)}$ for $\operatorname{dim} R=m \geqq 3$ will be called the capacity of $\gamma$.

\section{MODULAR CRITERION}

3. Moduli. Let $\Omega$ be a union of disjoint regular regions $\Omega_{j}$, $j=1, \cdots, k$. Suppose that $\partial \Omega_{j}$ consists of two nonempty disjoint sets $\beta_{j}^{\prime}$ and $\beta_{j}^{\prime \prime}$ which are unions of components of $\partial \Omega_{j}$. Set $\beta^{\prime}=\bigcup_{1}^{k} \beta_{j}^{\prime}$ and $\beta^{\prime \prime}=\bigcup_{1}^{k} \beta_{j}^{\prime \prime}$. Let $u_{0}$ be the continuous function on $\bar{\Omega}$ which is harmonic on $\Omega$ with $u_{0}\left|\beta^{\prime}=0, u_{0}\right| \beta^{\prime \prime}=\log \mu$, and $\int_{\beta} * d u_{0}=1$. The constant $\mu>1$ is called the modulus of the configuration $\left(\Omega, \beta^{\prime}, \beta^{\prime \prime}\right)$,

$$
\mu=\bmod \left(\Omega, \beta^{\prime}, \beta^{\prime \prime}\right) \text {. }
$$

The function $u_{0}$ is referred to as the modulus function.

Consider the family $U=U\left(\Omega, \beta^{\prime}, \beta^{\prime \prime}\right)$ of $C^{1}$-functions $u$ on $\bar{\Omega}$ which are harmonic on $\Omega$ with $\int_{\beta^{\prime}} * d u=1$. Then we have

$$
\min _{U} D_{\Omega}(u)=D_{\Omega}\left(u_{0}\right) \text {. }
$$

This follows from the identity

$$
D_{\Omega}(u)=D_{\Omega}\left(u_{0}-u\right)+D_{\Omega}\left(u_{0}\right)
$$

for every $u \in U$.

4. Modular criterion. Let $\widetilde{F}_{n}$ be the sum of those $F_{n}$ for which $\left\{F_{n}\right\}_{1}^{\infty}$ defines a boundary component in the subboundary $\gamma$. Consider 
$E_{n}=\left(R_{n+1}-\bar{R}_{n}\right) \cap \widetilde{F}_{n}$ and set $\gamma_{n}=\partial F_{n}, \gamma_{n}^{\prime}=\partial E_{n}-\gamma_{n}$. In terms of

$$
\mu_{n \gamma}=\bmod \left(E_{n}, \gamma_{n}, \gamma_{n}^{\prime}\right)
$$

we state:

THEOREM 1. If there exists an exhaustion of $R$ with

$$
\prod_{n=1}^{\infty} \mu_{n \gamma}=\infty,
$$

then the capacity of $\gamma$ vanishes.

In fact, let $p_{n}$ and $k_{n}$ stand for $p_{\gamma}$ and $k_{\gamma}$ with respect to $\gamma_{n}$ and $R_{n}$. By (1) we infer that

$$
D_{R_{n+1}-\bar{R}_{n}}\left(p_{n+1}\right) \leqq k_{n+1}-k_{n},
$$

and by (3) that

$$
\log \mu_{n \zeta} \leqq D_{E_{n}}\left(p_{n+1}\right) \text {. }
$$

Therefore $\log \mu_{n \gamma} \leqq k_{n+1}-k_{n}$, and we conclude that (6) implies

$$
\lim _{n \rightarrow \infty} k_{n}=\infty \text {. }
$$

On the other hand it is not difficult to see that $k_{r}=\lim _{n} k_{n}$, whence $c_{\gamma}=0$.

\section{Metric CRITERION}

5. Conformally equivalent metric. Let $\lambda$ be a positive $C^{\infty_{-}}$ function on $R$. The new metric

$$
d \sigma=\lambda d s
$$

is conformally equivalent to the original metric $d s$ on $R$. We fix a point $a \in R$ and assume that

$$
R(r)=\{x \in R \mid \sigma(x, a)<r\}
$$

is relatively compact in $R$ for $0<r<\infty$, with $R=\bigcup_{0<r<\infty} R(r)$. Consider the minimal union $\gamma(r)$ of components of $\beta(r)=\partial R(r)$ which separates $\gamma$ from $a$. Let

$$
S_{\gamma}(r)=\int_{r(r)} d S_{o},
$$

where $d S_{\sigma}$ is the surface element induced by $d \sigma$.

THEOREM 2. If there exists an admissible $\lambda$ such that 


$$
\int_{\varepsilon}^{\infty} \frac{d r}{S_{r}(r)}=\infty \quad(\varepsilon>0)
$$

then $\gamma$ has vanishing capacity for $R$ with $\operatorname{dim} R=2$. If, moreover, there exists a constant $M$ such that

$$
0<\frac{1}{M} \leqq \lambda \leqq M
$$

then the same conclusion holds regardless of the dimension of $R$.

For the proof we choose a sequence $\left\{r_{n}\right\}_{1}^{\infty}$ such that $\varepsilon<r_{n}<r_{n+1}<\infty$ and $\lim _{n} r_{n}=\infty$, with $R_{n}=R\left(r_{n}\right)$ regular. As in $\S 4$ we define $E_{n}=$ $\left(R_{n+1}-\bar{R}_{n}\right) \cap \widetilde{F}_{n}$ and $\mu_{n \gamma}$. We also denote by $u_{n}$ the corresponding modulus function.

The proof in the case $\operatorname{dim} R=2$ will be given in $\S 6$ and that in the general case under the assumption (11), in $\S 7$.

6. The case $\operatorname{dim} R=2$. Observe that

$$
\int_{E_{n}}\left|\nabla_{\sigma} u_{n}\right|^{2} d V_{\sigma}=\int_{r_{n}}^{r_{n}+1}\left[\int_{r(r)}\left|\nabla_{\sigma} u_{n}\right|^{2} d S_{\sigma} \int_{r(r)} d S_{\sigma}\right] \frac{d r}{S_{r}(r)} .
$$

By the Schwarz inequality we have

$$
\int_{r(r)}\left|\nabla_{\sigma} u_{n}\right|^{2} d S_{\sigma} \int_{r(r)} d S_{\sigma} \geqq\left(\int_{r(r)} *_{\sigma} d u_{n}\right)^{2} .
$$

Since $*_{\sigma}=*$ and $\left|\nabla_{\sigma} u_{n}\right|^{2} d V_{o}=\left|\nabla u_{n}\right|^{2} d V$, it is seen that (12), (13), and $D_{E_{n}}\left(u_{n}\right)=\log \mu_{n \gamma}$ imply

$$
\log \prod_{1}^{n} \mu_{k \gamma} \geqq \int_{r_{1}}^{r_{n+1}} \frac{d r}{S_{\gamma}(r)} .
$$

We conclude that (10) implies (6), and consequently $c_{\gamma}=0$.

7. The case $\operatorname{dim} R=m>2$. By (11) we see that

$$
\begin{aligned}
& \int_{E_{n}}\left|\nabla_{\sigma} u_{n}\right|^{2} d V_{\sigma} \leqq M^{m-2} D_{E_{n}}\left(u_{n}\right), \\
& \int_{\gamma(r)} *_{\sigma} d u_{n} \geqq M^{-(m-2)} \int_{\gamma(r)} * d u_{n} .
\end{aligned}
$$

Therefore (14) must be modified to give

$$
\log \prod_{1}^{n} \mu_{k \gamma} \geqq M^{-3(m-2)} \int_{r_{1}}^{r_{n+1}} \frac{d r}{S_{\gamma}(r)} .
$$


But this sufficient to conclude that $c_{\imath}=0$.

REMARK. Condition (11) cannot be suppressed in the case of higher dimensions.

The author is greatly indebted to Professor Leo Sario, chairman of his doctoral committee, who guided his research, and also to Professor Mitsuru Nakai, with whom the author had many invaluable discussions.

\section{REFERENCES}

1. L. Sario, Capacity of the boundary and of a boundary component, Ann. of Math. 59 (1954), 135-144.

2. L. Sario, M. Schiffer, and M. Glasner, The span and principal functions in Riemannian spaces, J. Analyse Math. 15 (1965), 115-134.

Received January 30, 1967. This work was sponsored in part by the U.S. Army Research Office-Durham, Grant DA-AROD-31-124-G742. The results of this paper are part of the author's dissertation at the University of California, Los Angeles.

University of California, Los Angeles 



\section{PACIFIC JOURNAL OF MATHEMATICS}

\section{H. ROYDEN}

Stanford University

Stanford, California

\author{
J. P. JANS \\ University of Washington \\ Seattle, Washington 98105
}

\section{EDITORS}

\author{
J. DugundJI \\ Department of Mathematics \\ Rice University \\ Houston, Texas 77001 \\ Richard ARENS \\ University of California \\ Los Angeles, California 90024
}

\section{ASSOCIATE EDITORS}
E. F. BECKENBACH
B. H. NeumanN
F. WOLF
K. YOSIDA

\section{SUPPORTING INSTITUTIONS}

\author{
UNIVERSITY OF BRITISH COLUMBIA \\ CALIFORNIA INSTITUTE OF TECHNOLOGY \\ UNIVERSITY OF CALIFORNIA \\ MONTANA STATE UNIVERSITY \\ UNIVERSITY OF NEVADA \\ NEW MEXICO STATE UNIVERSITY \\ OREGON STATE UNIVERSITY \\ UNIVERSITY OF OREGON \\ OSAKA UNIVERSITY \\ UNIVERSITY OF SOUTHERN CALIFORNIA
}

\author{
STANFORD UNIVERSITY \\ UNIVERSITY OF TOKYO \\ UNIVERSITY OF UTAH \\ WASHINGTON STATE UNIVERSITY \\ UNIVERSITY OF WASHINGTON \\ AMERICAN MATHEMATICAL SOCIETY \\ CHEVRON RESEARCH CORPORATION \\ TRW SYSTEMS \\ NAVAL ORDNANCE TEST STATION
}

Mathematical papers intended for publication in the Pacific Journal of Mathematics should be typewritten (double spaced). The first paragraph or two must be capable of being used separately as a synopsis of the entire paper. It should not contain references to the bibliography. Manuscripts may be sent to any one of the four editors. All other communications to the editors should be addressed to the managing editor, Richard Arens at the University of California, Los Angeles, California 90024.

50 reprints per author of each article are furnished free of charge; additional copies may be obtained at cost in multiples of 50 .

The Pacific Journal of Mathematics is published monthly. Effective with Volume 16 the price per volume (3 numbers) is $\$ 8.00$; single issues, $\$ 3.00$. Special price for current issues to individual faculty members of supporting institutions and to individual members of the American Mathematical Society: $\$ 4.00$ per volume; single issues $\$ 1.50$. Back numbers are available.

Subscriptions, orders for back numbers, and changes of address should be sent to Pacific Journal of Mathematics, 103 Highland Boulevard, Berkeley 8, California.

Printed at Kokusai Bunken Insatsusha (International Academic Printing Co., Ltd.), 7-17, Fujimi 2-chome, Chiyoda-ku, Tokyo, Japan.

PUBLISHED BY PACIFIC JOURNAL OF MATHEMATICS, A NON-PROFIT CORPORATION

The Supporting Institutions listed above contribute to the cost of publication of this Journal, but they are not owners or publishers and have no responsibility for its content or policies. 


\section{Pacific Journal of Mathematics}

A. A. Aucoin, Diophantine systems ............................. 419

Charles Ballantine, Products of positive definite matrices. I ............... 427

David Wilmot Barnette, A necessary condition for d-polyhedrality ............ 435

James Clark Beidleman and Tae Kun Seo, Generalized Frattini subgroups of finite groups ......................................... 441

Carlos Jorge Do Rego Borges, A study of multivalued functions ............. 451

William Edwin Clark, Algebras of global dimension one with a finite ideal

lattice ...............................................

Richard Brian Darst, On a theorem of Nikodym with applications to weak convergence and von Neumann algebras .........................

George Wesley Day, Superatomic Boolean algebras .....................

Lawrence Fearnley, Characterization of the continuous images of all

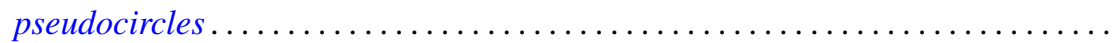

Neil Robert Gray, Unstable points in the hyperspace of connected subsets....... 515

Franklin Haimo, Polynomials in central endomorphisms .................. 521

John Sollion Hsia, Integral equivalence of vectors over local modular lattices . . . . 527

Jim Humphreys, Existence of Levi factors in certain algebraic groups .......... 543

E. Christopher Lance, Automorphisms of postliminal $C^{*}$-algebras ............ 547

Sibe Mardesic, Images of ordered compacta are locally peripherally metric . . . . 557

Albert W. Marshall, David William Walkup and Roger Jean-Baptiste Robert Wets,

Order-preserving functions: Applications to majorization and order

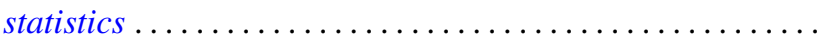

Wellington Ham Ow, An extremal length criterion for the parabolicity of

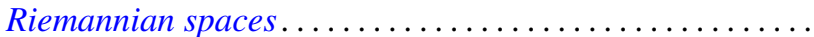

585

Wellington Ham Ow, Criteria for zero capacity of ideal boundary components of

Riemannian spaces...................................... 591

J. H. Reed, Inverse limits of indecomposable continua .................. 597

Joseph Gail Stampfli, Minimal range theorems for operators with thin spectra . . . 601

Roy Westwick, Transformations on tensor spaces..................... 613

Howard Henry Wicke, The regular open continuous images of complete metric

spaces ........................................... 621

Abraham Zaks, A note on semi-primary hereditary rings .............. 627

Thomas William Hungerford, Correction to: "A description of $\operatorname{Mult}_{i}\left(A^{1}, \cdots, A^{n}\right)$

by generators and relations" ............................. 629

Uppuluri V. Ramamohana Rao, Correction to: "On a stronger version of Wallis' formula".............................................. 629

Takesi Isiwata, Correction: "Mappings and spaces" ................... 630

Henry B. Mann, Josephine Mitchell and Lowell Schoenfeld, Correction to:

"Properties of differential forms in $n$ real variables" .... . .

James Calvert, Correction to: "An integral inequality with applications to the

Dirichlet problem"............................. 